\title{
Determining of agricultural credit impact on agricultural production value in Turkey
}

\author{
Nermin Bahşi ${ }^{*}$ (ID) Eray Çetin²
}

${ }^{1}$ Department of Organic Farming Business Management, Kadirli School of Applied Sciences, Osmaniye Korkut Ata University, 80760, Turkey. E-mail: nerminbahsi@osmaniye.edu.tr. "Corresponding author.

${ }^{2}$ Düziçi Vocational School, Osmaniye Korkut Ata University, 80600, Turkey.

\begin{abstract}
Agriculture is an indispensable activity for all countries. Depending on the increasing population, food needs can be met by increasing agricultural production. In this respect, it is of great importance to investigate the value of agricultural production and the factors affecting agricultural production. This study aimed to examine the impact on the agricultural production value of agricultural bank credit in Turkey. In the study, with the aim of examining the relationship between agricultural credit and agricultural production value in Turkey, 1998-2016 real agricultural loans and agricultural real gross domestic product annual data covering the period given above were used. The statistical analysis tool is ordinary least squares (OLS) techniques. According to OLS regression, the purposed model explains $83.94 \%$ of total variance. Regression coefficients show that effect of term is higher than effect of agricultural credits. The reason for this difference may be explained as dependency of credits on macroeconomic indicators and political structure of the country. This study proposes that agricultural credit mechanism in the country needs to be developed to increase the financing opportunities for the realization of technology and modernization investments by farmers.
\end{abstract}

Key words: agriculture, agricultural credits, agricultural gross domestic product, agricultural production, Turkey.

Determinação do impacto do crédito agrícola no valor da produção agrícola na Turquia

RESUMO: A agricultura é uma atividade indispensável para todos os paises. Dependendo do aumento da população, as necessidades alimentares podem ser atendidas através do aumento da produção agrícola. A esse respeito, é de grande importância investigar o valor da produção agrícola e os fatores que afetam a produção agrícola. Este estudo teve como objetivo examinar o impacto no valor da produção agrícola do crédito bancário agrícola na Turquia. No estudo, com o objetivo de examinar a relação entre crédito agrícola e valor da produção agrícola na Turquia, foram utilizados os empréstimos reais para 1998-2016 e os dados anuais do produto interno bruto agrícola real, cobrindo o periodo indicado acima. A ferramenta de análise estatística é uma técnica de mínimos quadrados ordinários (OLS). De acordo com a regressão OLS, o modelo proposto explica $83,94 \%$ da variância total. Os coeficientes de regressão mostram que o efeito do prazo é superior ao efeito dos créditos agrícolas. O motivo dessa diferença pode ser explicado como dependência de créditos em indicadores macroeconômicos e estrutura politica do país. Este estudo propõe que o mecanismo de crédito agricola no país precise ser desenvolvido para aumentar as oportunidades de financiamento para a realização de investimentos em tecnologia e modernização pelos agricultores.

Palavras-chave: agricultura, créditos agrícolas, produto interno bruto agrícola, produção agrícola, Turquia.

\section{INTRODUCTION}

Regarding its emergence and development, agriculture is known to be as old as humanity. Agricultural activities have become a practice of modern production techniques while inputs have continued to evolve further from primitive activities such gathering of wild plants as harvesting of trees, the collection of insects, and other small animal species and hunting. Besides, today agriculture is an area of activity for many countries, where high export revenues are obtained. Due to technology and innovation, the development process continues, and production techniques nearly integrated with computers are widely available.

Agriculture, like all countries in the world, has pivotal importance both in terms of its necessity for vitality and economical value for Turkey. In addition to meeting the need for food of people living in a country, agriculture is also essential as it provides inputs to other sectors operating in the economy, thus contributes to employment. Turkey, as well as with the vast agricultural land, has climate and other favorable conditions that enable agricultural activities 
to be held in every period of the year. Furthermore, soil fertility and the abundance of water resources support the extended production period. Also, the presence of forests and fields such as pastures and meadows allow animal husbandry to be carried out under suitable conditions along with crop production. The rural population and, consequently, the high proportion of people employable in agriculture is another element supporting agricultural activities. Agriculture in Turkey covers an extensive range of activities carried out by families who aim to ensure their livelihood while it is also carried out by large agricultural enterprises. The purpose of the enterprises operating in the agricultural sector, as in other sectors; to produce herbal and animal products using production factors and to generate income by marketing the products produced (OZDEN et al, 2012). Agricultural production increase, which is one of the basic elements of economic development, depends on targeted investments, implementing technological innovations and continuous production with increased efficiency (TERIN et al, 2014). Financing is of great importance in the provision of production factors and in the realization of agricultural activities (OZDEN et al, 2012). Credit is a basic and important necessity of the agricultural sector and any other commercial activity. Credit plays an important role in the commercialization and modernization of agriculture in rural economies (REHMAN et al, 2019). Agricultural credit is an important factor in the development of the production and investment structure of the agricultural sector in both developed and developing countries and is an important tool of agricultural development (ADANACIOGLU et al, 2017). Agricultural credit is very important in agriculture production because availability of credit removes financial constraints relating to cash inputs, secondly technical efficiency of farmers will increase and thirdly agricultural credit will increase resource allocation and profitability (SIAL et al, 2011).

Despite the progressive production and employment conditions, share in the total GDP value of agricultural production in Turkey declined from $12.5 \%$ in 1998 to $6.2 \%$ in 2016 . When the agricultural GDP is evaluated with the fixed prices of 2009 , it has increased approximately by $2 \%$ annually in the 18 -year period. The credits provided by the banks and, which are also used for agricultural production support increased by $39.4 \%$ in the same period. In the same period, both the value of agricultural production and agricultural credits boosted proportionally. However, the rate of increase in loans was higher than the value of agricultural production. It is necessary to emphasize the relationship between the financial support and the overall developments, as well as the transfer of credits provided from sources of finance. Depending on the developing and ever-changing production methods, there is also a shift and rise in the inputs. Funding sources are required to be able to produce in agriculture like it is in every sector. Credit is highly demanded in different parts of the world, mainly for capital requirement to improve land, purchase machinery, seeds, breeding stocks, and fertilizers as well as labor payment of wages (CHANDIO et al, 2017). Financing needs, which are derived from different options, arise to provide inputs for production, to acquire land and to aid the modernization process. Finally, in the provision of agricultural financing, many sources with or without organizational structures such as state banks, private banks, credit cooperatives, relatives, moneylenders are applied.

Agricultural credits play an essential role in making production more efficient and productive, especially in developing countries. In addition to aiding the problems of supplying farmers with required input during the periods, the sources of credits are used in many cases, such as the acquisition of agricultural land and equipment and modern technologies. Besides, the resources provided have the quality to enhance the farmers' entrepreneurial performance and their operational potentials. Expanding the loans provided for the purpose of funding the agricultural sector and providing easy access will ensure that the required inputs are obtained in a timely and at sufficient levels. This will also contribute to the increase of agricultural productivity and efficiency. Farmers who struggle with earning their lives will be able to invest and accumulate capital in accordance with the increase in agricultural productivity in this way. In Turkey, agriculture in general, due to it is carried out in the fragmented and small land by entrepreneurs who are among the group people with low-income, the investment capacity is rather low. This is one of the obstacles shaping agricultural development in the country. Owing to the inability to make the necessary investments, the low production volumes cause agricultural production values to be minimal. As a result, agricultural development is narrowed down to a limited area. Agricultural credit use is very important both for the producer and the national economy because of the agricultural enterprises' being small and fragmented, inadequacy of the owner's equity and the land's being an important part of the total capital (AKDEMIR et al, 2019).

Ciência Rural, v.50, n.11, 2020. 
Studies in the literature recommend that credit is one of the important inputs to meet the cash requirements of the farmers and play the role of a bridge leading from subsistence to cash economy and eventually to invisible surplus (SHAH et al., 2008). It is though that, it will contribute to the literature to investigation of the effect of agricultural credit on agricultural GDP in Turkey (which is a developing country), to determine the impact of the agricultural credit system in the country and it will enable comparison with other developing and developed countries. In this study, it is aimed to investigate the relationship between the credits obtained from banks, which have an organizational structure, and agricultural production value.

\section{Literatur review}

Aiming to reveal the relation between agricultural credits and agricultural production values, different theories were put forward, and various tests were carried out in this study. There are various studies in the literature addressing the same subject.

IQBAL et al. (2003), investigated the impact of institutional credit on agricultural production in Pakistan by using the ordinary least squares (OLS) method. In the study, Agricultural Gross Domestic Product (AGDP) was used as the dependent variable and agricultural production is assumed to be the function of water availability, agricultural labour force, cropped area, and agricultural credit. The data of the study, regarding variables of interest pertains to the financial years 1971-72 to 2001-2002. According the empirical results the relationship between institutional credit and agricultural GDP was found to be positive and significant.

SHAH et al. (2008), investigated the impact of agricultural credits on fertility and income of farmers who farm in the mountains in North Pakistan. In their findings, they found a positive relationship between farm productivity and agricultural credits. Another point where the positive relationship is valid is between agricultural credits and farms' income. Accordingly, the productivity and income of farmers who use agricultural loans increase depending on their timely and sufficient use of inputs.

AHMAD (2011), in his study, deals with the role of credit in the agricultural sector in Pakistan and examines the impact of agricultural loans on agricultural output. The study covers the period from 1974 to 2008 . According to the findings, credit plays an important role in the agricultural sector. In the study, agricultural output was used as dependent variable. The study is based on time series data and the Augmented Dicky Fuller test (ADF), and Phillips Perron test (PP) were used to examine the data stability. Since credit is disbursed in buying the expensive inputs like tractors, tube wells, seeds, and fertilizers, therefore; it was better justified to see the long-run impact and causality of credit, labor, cropped area, and water with agriculture output. According to empirical results, loans have a positive but insignificant effect on agricultural output. Hence the loan always helps to take various inputs for this sector and has an indirect role.

SALEEM \& JAN (2011) investigated the effects of credits on Agricultural Gross Domestic Product. They used data from 1990-2008, which included contributions from different sources, loans distributed for different purposes and contributions of the main products to the Agricultural Gross Domestic Product. Data were analyzed using linear regression model on The Cobb-Douglass type. Findings state that there is a strong relationship between fertilizers and drugs, irrigation and tractors, and agricultural gross domestic products. Relationship values were determined as $0.87,0.58$ and 0.42 , respectively. The above $80 \%$ impact was of credit on agricultural gross domestic product with $\mathrm{F}=10.752$ significant at $5 \%$. The evidence shows that the use of credit positively effects and increase overall agricultural production.

SIAL et al. (2011), investigated the role of institutional credit in agricultural production using the time series data for the period of 1972 to 2008 . In the study Cobb-Douglas production function was estimated using OLS and all the variables are transformed to per cultivated hectare. According the empirical results agricultural credit, availability of water, cropping intensity and agricultural labor force are positively significantly related to agricultural production.

TERIN et al. (2014), in their study, aimed to determine whether there is a causal relationship between agricultural production and the use of agricultural credits in Turkey. According to Granger causality analysis results, they found that there is a one-way causality between agricultural credits and agricultural production, from agricultural production to agricultural credits.

AGUNUWA et al. (2015) investigated the impact of credits on commercial agricultural loans in Nigeria by time series analysis as well. Results acknowledge that there is a positive relationship between the receiving funds from commercial banks and agricultural productivity. On the other hand, interest rates applied by banks have an adverse effect on productivity. 
AWOTIDE et al. (2015) investigated the effect of access to credit on agricultural productivity in Nigeria using the Endogenous Switching Regression Model (ESRM). The first step of the ESRM states that the total livestock unit and farm size are positive and statistically significant in determining farmers' access to credit. The second phase unclose that total livestock unit and farm size are negative and statistically significant in explaining the variations in cassava productivity among the farmers that have access to credit, meanwhile household size, farm size, and access to information assets are negative and statistically significant in explaining the variation in cassava productivity among the farmers without access to credit. According to the findings, access to credit has an important and positive effect on cassava production as well as agricultural production.

$$
\text { CHISASA \& MAKINA (2015) }
$$

investigated the dynamic relationship between bank loans and agricultural production in South Africa using time series data between 1970 and 2011 . Using the Johansen cointegration test, they observed bank loans and agricultural output. According to the findings, it was observed that loans and capital formation have a positive and significant effect on agricultural output. Using an ECM, they find that, in the short run, bank credit has a negative impact on agricultural output reflecting the uncertainties of institutional credit in South Africa. According to the empirical findings obtained from Granger Causality Tests uni-directional causality (1) from bank credit to agricultural output growth; (2) from agricultural output to capital formation; (3) from agricultural output to labor; (4) from capital formation to credit; (5) from capital formation to labor and there is a bi-directional causality between credit and labor. Findings show that the direction of causality for agricultural sector is realized from finance to economic growth. Alternatively, at the macroeconomic level, the direction of causality is from economic growth to financing.

NNAMOCHA \& EKE (2015) used timeseries data from the Nigerian Central Bank between 1970 and 2013, and in their work they aimed to identify the relationship between agricultural credits and agricultural output in Nigeria. As a result, they found a long-lasting relationship between agricultural credits and agricultural output.

CHANDIO et al. (2016), investigated the impact of area under wheat cultivation, water availability, credit disbursement and fertilizers offtake on wheat production in Pakistan using annual time series data over the period of 1982 to 2011.
The study employed a log-linear Cobb-Douglas production function in order to analyze the data. According the results, area under wheat cultivation, water availability, and credit disbursement has positive impact on wheat production and fertilizer off-take has a negative and no significant impact on wheat production. According the regression analysis, a1 percent increase in area under wheat cultivation increased wheat production by 1.20 percent tones; 1 percent increase in credit disbursement increased wheat production by 0.12 percent tones; 1 percent increase in water availability leads to increase in wheat production by 0.65 percent tones respectively.

UDOKA et al. (2016) examined the effect of commercial banks' loans on agricultural production in Nigeria. Four research hypotheses were developed to guide the study. Data were obtained from secondary sources, and they cover the period of 1970-2014. To estimate the specified equation, the ordinary least squares regression technique was employed. It was observed that there is a positive and significant relationship between agricultural credit guarantee scheme fund and agricultural production in Nigeria. It means that the increase in the agricultural credit, guarantee scheme fund may lead to an increase in agricultural production in Nigeria. There is also a positive and significant relationship between commercial banks' loans to agricultural sector and agricultural production in Nigeria. It is indicated that the increase in credit provided by commercial banks to the agricultural sector leads to an increase in agricultural production in return. However, there is a positive and significant relationship between the agricultural expenditures of the state and agricultural production in Nigeria and a negative relationship between interest rate and agricultural production. Such relations lead to an increase in the debt burdens as a result of the increase in the interest rate and accordingly, to the farmers who are in the debt to move towards less agricultural investment.

OGBUABOR \& NWOSU (2017) aimed to identify the impact of the agricultural credits of the deposit banks in Nigeria on agricultural productivity using the Error Correction Model. They used annual time series data covering the period 1981-2014. It was concluded that there is a relation between the variables within the scope of the obtained results. Besides, they pointed out that the agricultural loans provided by the deposit banks affect the agricultural productivity in the long run positively but that this effect does not occur in the short term.

REHMAN et al. (2017), investigated the relationship between the agricultural gross domestic 
product (AGDP) and variables, such as total food production, cropped area, loan disbursed by ZTBL, cooperative loan and total loan disbursed by various institutions in Pakistan. In the study, data were explored from 1960 to 2015; we used time series data collected from secondary sources, including the Pakistan Bureau of Statistics, Statistical Year Books and the Economic Survey of Pakistan and were analysed using the Phillips Perron (PP) test, and the results were interpreted using the Johansen Co-integration test. According the empirical results total food production, loan disbursed by ZTBL and the total loan disbursed by various institutions had a positive and significant influence on the AGDP, whereas cropped area and cooperatives loan had a negative but insignificant influence on the AGDP.

DURAMAZ \& TAS (2018), investigated the agricultural production effect of agricultural credits provided by the public, private and foreign banks in their work. As stated by the results of the analysis they obtained, the $10 \%$ increase in publicsector bank loans was realized as $3.2 \%$, the $10 \%$ increase in private bank loans was $0.4 \%$, and the $10 \%$ increase in agricultural production was found to increase by $0.1 \%$. According to these results, whatever the source is, the increase in agricultural credits causes an increase in agricultural production at the same time.

YALCINKAYA(2018), aimed to determine the effect of the loans used in the agricultural sector on the Gross Domestic Product and the effects of tracked loans in the agricultural sector on the GDP. In the study, Agricultural GDP (Gross Domestic Product), total GDP, agricultural sector loans, loans used by all sectors, tracked loans in agricultural sector, and tracked loan data in total loans were utilized. In order to investigate the effect of loans to the agricultural sector on GDP, a total of 40-period data were used quarterly between 2005 and 2015. Granger Causality Analysis was performed on these data. According to the findings, while agricultural loans are a Granger cause for agricultural GDP, agricultural GDP is not the cause of agricultural loans. There is bi-directional causality between agricultural GDP and total GDP, and variables are both causes and consequences. Tracked agricultural loans do not have a significant relationship with other variables. According to the findings, while agricultural loans have affected the GDP, tracked loans in agriculture do not affect GDP.

ADEMOLA (2019), investigated that the impact of agricultural finance on the growth of Nigerian economy. The research employed secondary data and econometric techniques of Ordinary Least
Square (OLS) of multiple regression estimates. According the results the productivity of investment will be more appropriately financed with resources administered by the commercial and specialized financial institutions. And also, that there are an urgent and sincere needs to expand the credit size to the agricultural sector in order to enhance the productivity growth of the sector.

KOC et al. (2019), investigated that the quantify the direct and spillover effects of Turkish agricultural domestic measures and agricultural credits use on the added agricultural value. The research applied a spatial panel model incorporating spatial interactions among the dependent and explanatory variables to evaluate the impact of government support and credit on Turkish agricultural output. A provincial data set of agricultural output values, input factors and government subsidies from 2004 to 2014 was used to model the spatial spillover effects of government supports. According the results a one percent increase in agricultural credits in a given province leads to an average increase of 0.17 percent overall in agricultural value-added per hectare, including 0.05 percent from the direct effect and 0.12 percent from the spillover effect. Contrary to agricultural credits, a one percent increase in government supports in a province generates a mixed direct and spillover effects, resulting in an overall reduction of 0.13 percent in agricultural value-added per hectare in Turkey.

REHMAN et al. (2019), investigated the relationship between agricultural gross domestic product (AGDP) and variables such as cropped area, fertilizer consumption, credit distribution and water availability in Pakistan Data were explored from 1978-2015. They used time series data collected from secondary sources, including the Pakistan Bureau of Statistics, Statistical Year Books and the Economic Survey of Pakistan. Data were analysed by using the Phillips-Perron (P-P) and Augmented Dickey Fuller (ADF) test, and results were interpreted by using the Johansen co-integration test. In the study, the CobbDouglas Production Function was used to examine the impact of these major factors on agricultural productivity in Pakistan. According the results, fertilizer consumption, improved seed distribution, and credit distribution had a positive and significant influence on AGDP, whereas water availability had a negative but insignificant influence on AGDP.

TAMBI \& BIME (2019), investigated that evaluate the impact of adequate financing on agricultural production in Cameroon by use made of control function modeling. Empirical results of 
research are based on 2007 household consumption survey and statistics from Ministry of Agriculture. According the results adequate financing is strongly correlated with agricultural production, while results by type and nature of agricultural credit show that personal financing, bank and micro-financial institution, family and partners, friends and tontines and institutional support is increasing agricultural production. Furthermore, subsidies in kind contribute more in augmenting agricultural production as compared to subsidies in cash.

\section{MATERIALS AND METHODS}

In the study, with the aim of examining the relationship between agricultural credit and agricultural production value in Turkey, 1998-2016 real agricultural loans and agricultural real gross domestic product annual data covering the period given above were used. The value of agricultural production (AGDP) constitutes the primary material of the study data which were obtained from Turkey Statistical Institute database (TUIK, 2018), and agricultural credits were provided by the Banks Association of Turkey (TBA, 2017). As for the conversion of series to the year 2009's fixed rates, Turkey Statistics Institution CPI series were used (TUIK, 2018). In addition, all of the data were included in the analyzes by taking logarithmic transformations to avoid the variance problem. In this study, Agricultural Production Value (LnAGDP) is the dependent variable, and Agricultural Credits $(\mathrm{LnAC})$ is the explanatory variable.

Conventionally, agricultural production function represents relationship between physical quantities of output and the inputs like land, labour, capital and quantities of other inputs (like water, fertiliser, pesticides etc.) (IQBAL et al, 2003; SALEEM \& JAN, 2011). Agricultural credit does not directly affect agricultural production, but it is used to provide inputs and new technologies used to increase agricultural production. In similar studies in the literature (IQBAL et al, 2003; SALEEM \& JAN, 2011; SIAL et al 2011); as agriculture is a multiproduct sector, agricultural credit is presented as a direct explanatory variable instead of inputs that can be purchased using credit.

The method to establish a relationship between bank credit and agricultural production value is the ordinary least squares (OLS) method. However, before predicting the model, the properties of the variables were evaluated in terms of stationarity and long-term relationship. In addition, the causality direction between these variables were determined.
Regression analysis involving two or more non-stationary time series can lead to false or meaningless regression. These tests are not reliable in the case of non-stationary time series because they assume that the time series on which they are based is stationary (GUJARATI, 2016). Since the data used in the study are time series, it is necessary to maintain the stability of these time series in order to avoid false regression results.

Structural changes, which may occur due to technological changes, political changes, etc., may cause breakage in the direction of regression. If the model is assessed without taking fracture into account, the defining error will have been made since the functional shape of the model will be incorrectly determined. Therefore, in this research, Augmented Dicky-Fuller (ADF), Phillips-Perron (PP) and Clemente-Montañés-Reyes Unit Root tests, which are structural fracture models were used to investigate the stationarity of time series and to stabilize nonstationary series.

A research on whether there is a long-term relationship between two or more non-stationary variables depends on the cointegration of the variables. Cointegration analysis is a method used to estimate long-term or equilibrium parameters among non-stationary variables (SEVUKTEKIN \& CINAR, 2014). Various cointegration tests reveal conflicting results. Therefore, Bayer-Hanck (2012) cointegration test was used, which evaluated ENGLE and GRANGER (1987), JOHANSEN (1988), BOSWIJK (1994) and BANERJEE et al. (1998) cointegration tests together. In addition to Bayer Hanck test for cointegration, Gregory Hansen test was also applied to data, in order to define cointegration breakpoint dates. Gregory Hansen method is a residual based method which allows endogenously determined structural break points (SADEGHI \& RAMAKRISHNA, 2014).

After the existence of cointegration was tested, it was tested whether there was a causal relationship between agricultural production value and agricultural credits. In order to analyze effects of long and short run, Granger causality test for VECM was used to analyze causality of agricultural credits and AGDP.

Bank loans are used to provide inputs to support existing production, to make new investments or to expand or develop existing investments. The funds obtained from various sources in the current period cause efficiency and productivity in production and affect the income of the future period. OLS regression with dummy time variable was use 
to test relationship between agricultural credits (AC) and AGDP.

Model:

$A G D P=\beta_{0}+\beta_{1} A C+\beta_{2} D U M M Y+U$

In order to avoid changing variance problem, logarithmic transformations are taken and included in the analysis and Equation 1 is transformed as follows:

$\operatorname{LnAGPD}=\beta_{0}+\beta_{1} \operatorname{LnAC}+\beta_{2} D U M M Y+U$

LnAGDP = natural logarithm

al gross domestic product.

$\mathrm{LnAC}=$ natural logarithm of agricultural

credits

DUMMY= Dummy variable for bad years (dummy=1 for years 2011-2016; dummy $=0$ for years 1998-2010).

$\mathrm{U}=$ Random error term independently and identically distributed with zero mean and constant variance.

All analysis were performed at StataMP 14.1 and Eviews for windows.

\section{RESULTS AND DISCUSSION}

\section{Stationarity analysis}

As for the stationarity analysis, the variables were subjected to the unit root test using the Augmented Dickey-Fuller, and PP tests and results are given in Table 1. Since the analysis results for the unit root test statistic values are lower than the absolute value of MacKinon critical value, series have unit root on the level value. Therefore, the relevant variables are not stable at $1 \%, 5 \%$, and $10 \%$ significance level. Consequently, ADF and PP unit root tests' statistics were recalculated regarding the initial differences of the data from the variables. The obtained unit root test statistic values became stationary for the output value due to being higher than MacKinon critical value as the absolute value. As a result, the relevant variables are stationary at a level of significance of $1 \%, 5 \%$, and $10 \%$. Furthermore, these findings indicate that it is possible to investigate the long-term relationship between the series (cointegration).

Clemente-Montañés-Reyes

(CMR)

Test was used to define two or more endogenous structural breaks for the unit root test (HOQUE \& BANERJEE, 2014). As for the stationary analysis, the variables were subjected to the unit root test using the Clemente-Montañés-Reyes unit-root test and results are given in Table 2. Since absolute values of the t-statistic were smaller than the $5 \%$ critical value, the relevant variables are not 5\% significance level.

Clemente-Montañés-Reyes unit-root test showed that 2011 was optimal breakpoint for both credit and GDP parameters. Thus, time period was divided into long run (1998-2011) and short run (2011-2016). In the examining period, two financial crises were occurred in Turkey in 2001 and 2008 global crisis. However, these two important dates were not found to be break points for agricultural credit and AGDP. This may be resulted from the fact that agricultural production in Turkey is very restricted, and most of GDP in the country relies on service sector. Thus, the main effects of the crises were seen in service sector.

\section{Cointegration analysis}

BAYER \& HANCK (2012) cointegration method combines all cointegration tests, and gives a reliable and efficient cointegration estimation (RAFINDADI \& OZTURK, 2017). A cointegration test (Bayer-Hanck Test) was used to determine if there was a long-term relationship between the

Table 1 - Stationarity test of the variable.

\begin{tabular}{|c|c|c|c|c|c|c|c|}
\hline & \multirow[b]{2}{*}{ Değişkenler } & \multicolumn{2}{|c|}{------ADF test statistic------- } & \multicolumn{2}{|c|}{--------PP test statistic--------- } & \multicolumn{2}{|c|}{----Test critical values---- } \\
\hline & & t-Statistic & Prob. ${ }^{*}$ & t-Statistic & Prob. ${ }^{*}$ & $1 \%$ & -4.571 .559 \\
\hline \multirow{2}{*}{$\begin{array}{l}\text { Level - } \\
\text { Fixed and Trend }\end{array}$} & LnAGDP & -3.196 .719 & 0.1160 & -3.194211 & 0.1165 & $5 \%$ & -3.690 .814 \\
\hline & LnAC & 0.168263 & 0.9951 & 0.122860 & 0.9947 & $10 \%$ & -3.286 .909 \\
\hline \multirow{3}{*}{$\begin{array}{l}\text { First } \\
\text { differentiation } \\
\text { Fixed and Trend }\end{array}$} & LnAGDP & -6.474 .487 & 0.0004 & -10.52059 & 0.0000 & $1 \%$ & -4.616 .209 \\
\hline & LnAC & -6.996 .053 & 0.0002 & -13.44384 & 0.0000 & $5 \%$ & -3.710 .482 \\
\hline & & & & & & $10 \%$ & -3.297 .799 \\
\hline
\end{tabular}

Ciência Rural, v.50, n.11, 2020. 
Table 2 - Clemente-Montañés-Reyes unit-root test with single mean shift.

\begin{tabular}{lcccc}
\hline & du1 & (rho-1) & Constant & optimal break point \\
\hline AC & & & \\
Coefficient & 259268000,00 & -0.65733 & 2994000,00 \\
\hline $\mathrm{t}$ & 7.686 & -4.249 & \\
$\mathrm{p}$ & 0.000 & $-3.560(5 \% \mathrm{CV})$ & \\
$\mathrm{AGDP}$ & & & 75570000,00 \\
\hline Coefficient & 21975400,00 & -0.47213 & \\
$\mathrm{t}$ & 6.140 & -2.210 & \\
$\mathrm{p}$ & 0.000 & $-3.560(5 \% \mathrm{CV})$ & \\
\hline
\end{tabular}

variables. Results showed that null hypothesis was accepted (Table 3). In other words, there was no cointegration between variables of the research. It shows that there is no long-term relationship between the series discussed as a result of cointegration test. Absence of cointegration between variables shows that there was not a colinearity which affects results of OLS, DOLS and FMOLS regressions. This finding increases power of the results.

In addition to Bayer Hanck test for cointegration, Gregory Hansen test was also applied to data, in order to define cointegration breakpoint dates. Gregory Hansen method is a residual based method which allows endogenously determined structural break points (SADEGHI \& RAMAKRISHNA, 2014). Results were given in the Table 4.

Since absolute values of critical values are higher at $1 \%, 5 \%$ and $10 \%$ levels, it was seen that series were not cointegrated. On the other hand, two breakpoints were found as 2001 and 2003. In CMR test, 2011 was found as optimal breakpoint. Thus, 2001 and 2003 breakpoints were evaluated as cointegration breakpoints.

\section{VEC model for short and long run results}

VEC Model is used if (i) the variables are cointegrated, or (ii) the time series are not stationary in their levels, but are in their differences (ANONYMOUS, 2019; SUHARSONO et al, 2017). In Vector Error Correction Model (VECM), LnAGDP, LnAC and term as a dummy variable were analyzed. Results were given in the Table 5 .

VECM parameters showed that credits had $49.95 \%$ cumulative variance explained, whereas AGDP had $47.00 \%$ and term had $21.7 \%$ cumulative variance explained. This results shows that credits had more vector error correction fit than AGDP and term. In other words, credits may have higher error correction needed nature. In order to analyze effects of long and short run, Granger causality test for VECM was used to analyze causality of agricultural credits and AGDP and results were given in the Table 6.

While TERIN et al. (2014), found that there was a one-way causality between agricultural credits and the agricultural production with the direction of being from the agricultural production to agricultural credit based on Granger causality analysis results, NNAMOCHA \& EKE (2015) found no causality relationship between the variables. In this study, there was no causality relationship between agricultural credits and agricultural GDP. Although agricultural credits had significant effect on agricultural GDP, it is not a Granger cause of

Table 3 - Bayer-Hanck Test for Cointegration.

\begin{tabular}{lcccc}
\hline & Engle-Granger & Johansen & Banerjee & Boswijk \\
\hline $\mathrm{p}$ values & 0.4895 & 0.3153 & 0.7141 & 0.8476 \\
Test statistics & -2.0652 & 9.3218 & -1.3223 & 1.7499 \\
EG-J & 3.7372031 & $11.229(5 \% \mathrm{CV})$ & & \\
EG-J-Ba-Bo & 4.7413605 & $21.931(5 \% \mathrm{CV})$ & & \\
\hline
\end{tabular}

Ciência Rural, v.50, n.11, 2020. 
Table 4 - Gregory Hansen Cointegration Test.

\begin{tabular}{lcccrr}
\hline Lags=2 & Test Statistic & Date & 1\% CV & \multicolumn{2}{c}{$5 \% \mathrm{CV}$} \\
\hline $\mathrm{ADF}$ & -4.67 & 2003 & -5.44 & -4.92 & -4.69 \\
$\mathrm{Zt}$ & -3.92 & 2001 & -5.44 & -4.92 & -4.69 \\
$\mathrm{Za}$ & -16.44 & 2001 & -57.01 & -46.98 & -42.49 \\
\hline
\end{tabular}

agricultural GDP. This result indicates that there are other factors significantly effecting agricultural GDP besides agricultural credits.

\section{OLS Regression for parameter relations}

After determining the causality relationship between the variables, the effect of agricultural credits on real agricultural GDP was determined by regression analysis. OLS regression with dummy time variable was use to test relationship between agricultural credits and AGDP. Including term variable as a dummy variable also gives opportunity to determine controlled regression results. Thus, regression estimations with OLS, DOLS and FMOLS had higher estimation levels. Results were given in the Table 7.

According to OLS regression, the purposed model explains $83.94 \%$ of total variance. Regression coefficients show that effect of term is higher than effect of agricultural credits. The reason for this difference may be explained as dependency of credits on macroeconomic indicators and political structure of the country.

The AGDP, as the model of agricultural credits, is statistically significant as a whole. The corrected coefficient of determination of the model is calculated as 0.8394 . All the coefficients of the variables are statistically significant at the 0.01 significance level, and the theoretical expectation in terms of their signs is suitable. According to the model's estimation results, the AGDP - short-term flexibility of agricultural credits is above 0.05 . Accordingly, a $10 \%$ real increase (decrease) in agricultural credits leads to a $0.5 \%$ increase (decrease) in real AGDP in the current year. Long-term flexibility is more significant than it is in the short term because of the delayed effects of credits over income. In the model, AGDP was estimated to be 0.02 for long-term flexibility of agricultural credits. The adaptation coefficient of the model was found to be 0.17 . Accordingly, $17 \%$ of the difference between long-term, equilibrium, or the desired amount of agricultural GDP and the current or observed agricultural GDP is reduced each year. Findings in the literature show that agricultural credits positively affect agricultural productivity (SHAH et al., 2008; AYAZ \& HUSSAIN, 2011; SALEEM \& JAN, 2011; AGUNUWA et al. 2015; AWOTIDE et al. 2015; CHISASA \& MAKINA, 2015; NNAMOCHA \& EKE, 2015; UDOKA et al. 2016; OGBUABOR \& NWOSU, 2017; DURAMAZ \& TAS, 2018; ADEMOLA, 2019; TAMBI \& BIME, 2019). IQBAL et al. (2003), SIAL et al. (2011), REHMAN et al (2017), KOC et al. (2019); REHMAN et al (2019), found that agricultural credits have a positive and statistically significant effect on agricultural GDP. Studies in the literature and this study proved the effect of agricultural loans on agricultural production value and agricultural production amount.

In order to check estimated models with robustness, FMOLS and DOLS tests were also used (Table 8). Since time variable labelled as long and short term as a dichotomous variable, long term coded

Table 5 - VECM for parameters of the research.

\begin{tabular}{|c|c|c|c|c|}
\hline & RMSE & R-sq & chi2 & $\mathrm{p}>$ chi 2 \\
\hline D_LnAC & 0.446135 & 0.4995 & 11.97709 & 0.0351 \\
\hline D_LnAGDP & 0.047608 & 0.4700 & 10.64142 & 0.0590 \\
\hline D_Term (dummy) & 0.255345 & 0.2176 & 3.337229 & 0.6481 \\
\hline
\end{tabular}

Ciência Rural, v.50, n.11, 2020. 
Table 6 - Granger causality test for VECM.

\begin{tabular}{lccc}
\hline Null hypothesis & Chi-sq & df & Prob. \\
\hline AGDP does not Granger cause AC & 0.94 & 2 & 0.6257 \\
AC does not Granger cause AGDP & 0.29 & 2 & 0.8668 \\
\hline
\end{tabular}

as event (1), and short term was coded as non event (0). Effects of other relevant variables were stochastically evaluated by OLS regression with equation constant. FMOLS and DOLS for robustness of estimated results were also accordance with estimated results. Corrected R2 indicating explanatory of the model was the highest in DOLS model, followed by OLS and FMOLS model.

\section{CONCLUSION}

While a significant portion of total loans in Turkey is composed of credits for consumption, the role of agricultural credits is increasingly essential in the growth of the agricultural sector, which directly supports country production. However, the share of newly opened agricultural credits in the total credits of the banking system is still very low (SEVEN, 2016).

In this study, the effect of the use of agricultural credits in Turkey, during the period of 1998-2016 over agricultural production value was examined. OLS regression with dummy time variable was use to test relationship between agricultural credits and AGDP. In order to check estimated models with robustness, FMOLS and DOLS tests were also used. The results of the regression analysis reveal the relationship between agricultural production value and agricultural credits. Accordingly, a 10\% real increase (decrease) in agricultural credits leads to a $0.5 \%$ increase (decrease) in real AGDP in the current year. The low of this rate may be due to the fact that agricultural credits are not a direct input in agricultural production. Although agricultural credits do not directly contribute to agricultural production value and agricultural production, they constitute an important source in purchasing inputs to be used in agricultural production increase and making new investments. In order to ensure the development in agriculture, it is important to develop policies that will provide attractive lending to producers. In addition, as agricultural credits to be provided by funding sources become more widely available, more accessible, and being converted into an agricultural development program, the value of agricultural production will boost depending on the agricultural credits to be used, and this will have a positive impact on AGDP.

Increased productivity can be achieved with the help of using high technology in agriculture

Table 7 - OLS regression with dummy time variable for LnAGDP.

\begin{tabular}{|c|c|c|c|c|}
\hline & coefficient & St. Error & $\mathrm{t}$ & Significance \\
\hline Constant Term & 17.46931 & 0.1031796 & 169.31 & $<0.001$ \\
\hline LnAC & 0.0456674 & 0.0071738 & 6.37 & $<0.001$ \\
\hline Term (Dummy) & 0.1317707 & 0.286835 & 4.59 & $<0.001$ \\
\hline $\mathrm{R}^{2}$ & 0.8573 & & & \\
\hline Corrected $\mathrm{R}^{2}$ & 0.8394 & & & \\
\hline$F(2,16)$ & 48.05 & & & \\
\hline Root MSE & 0.76516 & & & \\
\hline Short-term AGDP- Credit Elasticity & 0.05 & & & \\
\hline Long-term AGDP- Credit Elasticity & 0.02 & & & \\
\hline Adaptation Coefficient & 0.17 & & & \\
\hline
\end{tabular}

Ciência Rural, v.50, n.11, 2020. 
Table 8 - FMOLS and DOLS for robust tests of cointegration.

\begin{tabular}{|c|c|c|c|c|c|c|}
\hline & $\operatorname{Ln} A C$ & Term (Dummy) & C & $\operatorname{Ln} A C$ & Term (Dummy) & C \\
\hline Coefficient & 0.0474 & 0.1430 & 17.4410 & 0.0484 & 0.1485 & 17.4372 \\
\hline Std Error & 0.0067 & 0.0243 & 0.0984 & 0.0067 & 0.0264 & 0.0992 \\
\hline $\mathrm{t}$ & 7.0287 & 5.8744 & 177.1917 & 7.2406 & 5.3639 & 175.7368 \\
\hline $\mathrm{p}$ & 0.0000 & 0.0000 & 0.0000 & 0.0002 & 0.0010 & 0.0000 \\
\hline Corrected $\mathrm{R}^{2}$ & 0.9093 & & & 0.9131 & & \\
\hline Long-run variance & 0.0011 & & & 0.0006 & & \\
\hline Sum squared resid & 0.0285 & & & 0.0110 & & \\
\hline
\end{tabular}

and modernization of equipment. However, due to the effect of income levels of farmers involved in agricultural areas in Turkey and as a result of their lack of savings which are to be reinvested, modernization in production can not be achieved. Agricultural credit mechanism in the country needs to be developed to increase the financing opportunities for the realization of technology and modernization investments by farmers. Consequently, an increase in overall yield can be achieved in agricultural production. KUSEK et al. (2017), stated that the creation of new agricultural financing models to meet the working capital needs of all agricultural enterprises, especially small-scale enterprises, and the development of special financing models to reduce investment costs. They also stated that a special guarantee system should be established for the collateral required for agricultural financing.

Producers in Turkey operating in the agricultural field vary significantly in terms of qualitative features of the production factors they have and in terms of technologies and methods they use in production. Accordingly, the size of the enterprise and agricultural output and incomes are also different. In particular, agricultural credits to be provided through state banks should be different considering such differences between small farmers and larger farmers. Smaller farmers who have difficulty in payment should be provided with lower interest rates and long-term loans, especially to be used in investment expenditures, in order to be supported economically.

\section{ACKNOWLEDGEMENTS}

No financial support received.

\section{DECLARATION OF CONFLICTS OF INTERESTS}

The authors declared no potential conflicts of interest with respect to the research, authorship, and/or publication of this article.

\section{AUTHORS' CONTRIBUTIONS}

All authors contributed equally for the conception and writing of the manuscript. All authors critically revised the manuscript and approved of the final version.

\section{REFERENCES}

ADANACIOGLU, $H$. et al.,. Analysis of agricultural credit performance in Turkey by multi-dimensional scaling approach. Turkish Journal of Agricultural Economics, v.23, n.2, p.195204, 2017. Available from: <http://static.dergipark.org.tr:8080/ article-download/6feb/ca66/5f9c/5c337f42b06db.pdf?> Accessed: May, 5, 2018. doi: 10.24181/tarekoder.364932.

ADEMOLA, A.E. Impact of agricultural financing on Nigeria economy. Asian Journal of Agricultural Extension, Economics \& Sociology, v.31, n.2, p.1-13, 2019. Available from: <http://www.journalajaees.com/index.php/AJAEES/article/ view/30130/56528>. Accessed: Jan. 02, 2020. doi: 10.9734/ ajaees/2019/v31i230130.

AGUNUWA, E.V. et al. Impact of commercial banks' credit on agricultural productivity in Nigeria (time series analysis 1980 2013). International Journal of Academic Research in Business and Social Sciences, v.5, n.11, p.337-350, 2015. Available from: $<$ http://dx.doi.org/10.6007/IJARBSS/v5-i11/1921>. Accessed: May, 5, 2018. doi: 10.6007/IJARBSS/v5-i11/1921.

AHMAD, N. Impact of Institutional Credit on Agricultural Output: A Case Study of Pakistan. Theoretical and Applied Economics, v.10, n.563, p.99-120, 2011. Available from: < http://store.ectap.ro/ articole/653.pdf >. Accessed: Jan. 1, 2019.

AKDEMIR, S. et al. Factors Affecting The Credit Use Of Farmers: Sample Of Subprovince Of Tarsus, Province Of Mersin. FebFresenius Environmental Bulletin, v.4729, 2019. Available from: $<$ https://www.prt-parlar.de/download_feb_2019/ > . Accessed: Apr. $26,2020$.

ANONYMOUS. Vector Error Correction Models (VECM), 2019. Available from: <http://www.learneconometrics.com/class/5263/ notes/gretl/Vector\%20Error\%20Correction\%20Models_gretl. pdf $>$. 2019. Accessed: Jan. 3, 2020.

AWOTIDE, B.A. et al. Impact of access to credit on agricultural productivity: evidence from smallholder cassava farmers in Nigeria. In: 29 th INTERNATIONAL CONFERENCE AGRICULTURAL 
ECONOMISTS, 8-14 August 2015, Italy, p.1-33, 2015. Available from: <http://www.icae2015.org/>. Accessed: May, 52018.

AYAZ, S.; HUSSAIN, Z. Impact of institutional credit on production effciency of farming sector a case study of district Faisalabad. Pakistan Economic and Social Review, v.49, n.2, p.149-162, 2011. Available from: <http://pu.edu.pk/images/ journal/pesr/PDF-FILES/1\%20AYAZ\%20Impact $\% 20$ of $\% 20$ Institutional $\% 20$ Credit $\% 20$ on $\% 20$ Production $\% 20$ Effici_.pdf $>$. Accessed: May, 5, 2018.

BANERJEE, A. et al. Error-correction mechanism tests for cointegration in a single-equation framework. Journal of Time Series Analysis, v.19, n.3, p.267-283, 1998. Available from: $\quad<$ https://onlinelibrary.wiley.com/doi/epdf/10.1111/14679892.00091>. Accessed: Jan, 28, 2019. doi: 10.1111/14679892.00091 .

BAYER, C.; HANCK, C. Combining Non-Cointegration Tests. Journal of Time Series Analysis, v.34, n.1, p.83-95, 2012. Available from: <https://onlinelibrary.wiley.com/doi/ epdf/10.1111/j.1467-9892.2012.00814.x>. Accessed: Apr. 28, 2020. doi: 10.1111/j.1467-9892.2012.00814.x.

BOSWIJK, H.P. Testing for an Unstable Root in Conditional and Structural Error Correction Models. Journal of Econometrics, v.63, n.1, p.37-60, 1994. Available from: <https://www. sciencedirect.com/science/article/abs/pii/0304407693015609 > Accessed: Jan. 28, 2019. doi: 10.1016/0304-4076(93)01560-9.

CHANDIO, A. A. et al.. Impact of area under cultivation, water availability, credit disbursement, and fertilizer off-take on wheat production in Pakistan. Journal of Applied Environmental and Biological Sciences, v.6, n.10, p.10-18, 2016. Available from: $\quad<$ https://www.textroad.com/pdf/JAEBS/J.\%20Appl.\%20 Environ.\%20Biol.\%20Sci.,\%206(10)10-18,\%202016.pdf>. Accessed: Apr. 21, 2020.

CHANDIO, A. A. et al. Farmers' access to credit: Does collateral matter or cash flow matter?-Evidence from Sindh, Pakistan. Cogent Economics \& Finance, v.5, n.1, 1369383, 2017. Available from: <https://www.tandfonline.com/doi/full/10.10 80/23322039.2017.1369383>. Accessed: Apr. 21, 2020. doi: $10.1080 / 23322039.2017 .1369383$.

CHISASA, J.; MAKINA, D. Bank credit and agricultural output in South Africa: cointegration, short run dynamics and causality. The Journal of Applied Business Research, v.31, n.2, p.489-500, 2015. Available from: $<$ https://clutejournals.com/index.php/JABR/ article/view/9148/9139>. Accessed: Jan. 29, 2019. doi: 10.19030/ jabr.v31i2.9148.

DURAMAZ, S.; TAS, T. The effect of agricultural credits which have been granted by public, private and foreign capital banks on agricultural production: panel data analysis with aegean region datas. Int. Journal of Management Economics and Business, v.14, n.1, p.35-50, 2018. Avaliable from: <http://ijmeb.org/index. php/zkesbe/article/view/1552/pdf > . Accessed: May, 5, 2018. doi: 10.17130/ijmeb.2018137572.

ENGLE, R.F.; GRANGER, C.W. Co-integration and error correction: representation, estimation, and testing. Econometrica: Journal of the Econometric Society, 251-276, 1987. Avaliable from: $\quad<$ https://www.jstor.org/stable/1913236?seq=1\#metadata info tab contents $>$. Accessed: May, 5, 2018. doi: 10.2307/1913236.
GUJARATI, D. Econometrics by Example. 2 ed. (Translated N Bolatoğlu). Ankara: BB101 Publishing, 1st Edition, 2016. 565p.

HOQUE, A.; BANERJEE, R. The Stationarity of South Asian Real Exchange Rates Allowing for Structural Breaks, Australasian Accounting, Business and Finance Journal, v.8, n.3,p. 45-54, 2014. Available from: <https://ro.uow.edu.au/aabfj/vol8/iss3/4/> Accessed: Jan. 3, 2020. doi: 10.14453/aabfj.v8i3.4.

IQBAL, M. et al. The impact of institutional credit on agricultural production in Pakistan [with comments]. The Pakistan Development Review, p.469-485, 2003. Available from: $<$ https://ideas.repec.org/p/pra/mprapa/3673.html>. Accessed: Apr. 15, 2020.

JOHANSEN, S. "Statistical analysis of cointegration vectors", Journal of Economic Dynamics and Control, 12, p. 231-254, 1988. Avaliable from: <https://www.sciencedirect.com/science/ article/pii/0165188988900413>. Accessed: Jan. 3, 2020. doi: 10.1016/0165-1889(88)90041-3.

KOC, A.A. et al. Effects of government supports and credits on Turkish agriculture: A spatial panel analysis. Journal of Agribusiness in Developing and Emerging Economies, v.9, n.4, p.391-401, 2019. Available from: <https://www.emerald. com/insight/content/doi/10.1108/JADEE-11-2018-0164/full/ pdf?title=effects-of-government-supports-and-credits-on-turkishagriculture-a-spatial-panel-analysis $>$. Accessed: Jan. 2, 2020. doi: 10.1108/JADEE-11-2018-0164

KUSEK, G. et al. Structural characteristics of the agricultural sector in terms of access to agricultural credits in Turkey. New Medit, n.4, p.66-72, 2017. Available from: <https://newmedit. iamb.it/share/img_new_medit_articoli/1123_66kusek.pdf $>$. Accessed: Nov. 1, 2019.

NNAMOCHA, P.N.; EKE, C.N. Bank credit and agricultural output in Nigeria (1970 - 2013): An error correction model (ecm) approach. British Journal of Economics, Management \& Trade, v.10, n.2, p.1-12, 2015. Available from: <http://www.journaljemt. com/index.php/JEMT/article/view/12016/21908>. Accessed: May, 5, 2018. doi: 10.9734/BJEMT/2015/19884.

OGBUABOR, J. E.; NWOSU, C.A. The impact of deposit money bank's agricultural credit on agricultural productivity in Nigeria: Evidence from an error correction model. International Journal of Economics and Financial Issues, v.7, n.2, p.513-517, 2017. Available from: <http://www.econjournals.com/index.php/ijefi/ article/view/4118/pdf>. Accessed: May, 5, 2018.

OZDEN, F., et al.Kırsal Kesimde Tarımsal Kredi Kullanımı ve Tarım İşletmesi Üzerine Etkileri: İzmir ili Torbalı İlçesi Örneği. 10. Ulusal Tarım Ekonomisi Kongresi, 5-7, 2012. Available from: $<$ http://www.tarimarsiv.com/wp-content/uploads/2017/05/99-105. pdf $>$. Accessed: Jan. 29, 2019.

RAFINDADI, A.A.; OZTURK, I. Dynamic Effects of Financial Development, Trade Openness and Economic Growth on Energy Consumption: Evidence from South Africa. International Journal of Energy Economics and Policy, v.7, n.3, p.74-85, 2017. Available from: $<$ https://www.econjournals.com/index.php/ ijeep/article/view/4690/2995>. Accessed: Jan. 3, 2020.

REHMAN, A. et al. Is credit the devil in the agriculture? The role of credit in Pakistan's agricultural sector. The Journal of Finance and Data Science, v.3, n.1-4, p.38-44, 2017. Available from: <https:// 
www.sciencedirect.com/science/article/pii/S2405918817300223>. Accessed: Apr. 21, 2020. 10.1016/j.jfds.2017.07.001.

REHMAN, A. et al. Fertilizer consumption, water availability and credit distribution: Major factors affecting agricultural productivity in Pakistan. Journal of the Saudi Society of Agricultural Sciences, v.18, n.3, p.269-274, 2019. Available from: <https://www. sciencedirect.com/science/article/pii/S1658077X17301625>. Accessed: Jan. 02, 2020. 10.1016/j.jssas.2017.08.002.

SADEGHI, A.; RAMAKRISHNA, G. An Empirical Analysis of Imports of Iran: A Gregory Hansen Method of Cointegration. American Journal of Business, Economics and Management v.2, n.4, p.105-112, 2014. Available from: <http://www.ijbmer. com/docs/volumes/vol5issue2/ijbmer2014050202.pdf $>$. Accessed: Jan. 03, 2020.

SALEEM, M.A.; JAN, F.A. The impact of agricultural credit on agricultural productivity in Dera Ismail Khan (District) Khyber Pakhtonkhawa Pakistan. European Journal of Business and Management, v.3, n.2, 2011. Available from: $<\mathrm{https}: / / \mathrm{www} . i i s t e$. org/Journals/index.php/EJBM/article/view/159/43>. . Accessed: May, 05, 2018

SEVEN, U. Tarım bankacılı̆ğının tarımsal verimlilik üzerindeki etkileri. 2016. Available from: <http:/tcmbblog.org/wps/ $\mathrm{wcm} / \mathrm{connect} / \mathrm{blog} / \mathrm{tr} / \mathrm{main}+\mathrm{menu} /$ analizler/tarim_bankaciligi $>$ Accessed: Nov. 28, 2017

SEVUKTEKIN, M.; CINAR, M. Econometric Time Series Analysis, Eviews Applied. Bursa: Dora Publishing, Expanded 4th Edition, 2014. 667p

SHAH, M.K. et al. Impact of agricultural credit on farm productivity and income of farmers in mountanous agriculture in Northern Pakistan: A case study of selected villages in district Chitral. Sarhad J. Agric, v.24, n.4, p.713-718, 2008. Available from: $\quad<$ https://www.aup.edu.pk/sj_pdf/impact $\% 20$ of $\% 20$ agricultural $\% 20$ credit $\% 20$ on $\% 20$ farm $\% 20$ productivity $\% 20$ and pdf>. Accessed: May, 05, 2018.

SIAL, M.H. et al. Role of institutional credit on agricultural production: a time series analysis of Pakistan. International Journal of Economics and Finance, v.3, n.2, p.126-132, 2011.
Available from: <https://mpra.ub.uni-muenchen.de/31815/1/ MPRA_paper_31815.pdf $>$. Accessed: Apr. 21, 2020. doi:10.5539/ ijef.v3n2p.

SUHARSONO, A. et al. Comparison of Vector Autoregressive (VAR) and Vector Error Correction Models (VECM) for Index of ASEAN Stock Price. In: INTERNATIONAL CONFERENCE AND WORKSHOP ON MATHEMATICAL ANALYSIS AND ITS APPLICATIONS (ICWOMAA, 2017), Published Online: 05 December 2017 Available from: <https://aip.scitation.org/doi/ abs/10.1063/1.5016666>. Published Online: 05 December 2017. Accessed: Jan. 3, 2020. doi: 10.1063/1.5016666

TAMBI, M.D.; BIME, W.M.J. Adequate financing and agricultural production: response to new generation agriculture in Cameroon. Journal of Agribusiness Sciences, v.3, n.1, p. 1-15, 2019. Available from: <http://jurnal.umsu.ac.id/index.php/JASc/article/ view/3557/pdf 40>. Accessed: Jan. 01, 2020.

TBA. Turkey Banks Association, Statistical Reports, 2017 Available from: <https://www.tbb.org.tr/tr/bankacilik/banka-vesektor-bilgileri/istatistiki-raporlar/59>. Accessed: Nov. 23, 2017.

TERIN, M.; et al. Causal relationship between agricultural production and agricultural credit use in Turkey. Iğdır Univ. J. Inst. Sci. \& Tech., v.4, n.1, p.67-72, 2014. Available from: <http:// www.igdir.edu.tr/Addons/Resmi/announc/247/mart2014-67-72. pdf $>$. Accessed: May, 04, 2018.

TUIK. Turkey Statistical Institute, Statistics according to Subject. 2018. Available from: $<$ http://www.tuik.gov.tr/UstMenu. do?metod=kategorist $>$. Accessed: May, 02, 2018.

UDOKA, C.O. et al. The Effect of Commercial Banks' Credit on Agricultural Production in Nigeria. Journal of Finance and Accounting, v.4, n.1, p.1-10, 2016. Available from: <http://pubs. sciepub.com/jfa/4/1/1/index.html >. Accessed: May, 05, 2018. doi: $10.12691 / \mathrm{jfa}-4-1-1$.

YALCINKAYA, S. Determination of Effect of Agricultural Credits on Economy by Granger Causality Analysis, JKEM, v.13, n.1, p.51-61, 2018. Available from: <http://www.beykon.org/ dergi/2018/FALL/2018XIII.I.4.H.S.Yalcinkaya.pdf>. Accessed: Jan. 29, 2019 . 